\title{
Nodehandel i København i 1600-tallet
}

\author{
afmusikforsker, ph.d. Bjarke Moe, \\ Dansk Center for Musikudgivelse
}

$\mathrm{D}$ et er en kendt sag, at musik i form af noder cirkulerede på tværs af Europa i den tidlige moderne tid. Musikere rejste rundt på kontinentet for at uddanne sig eller for at søge arbejde væk fra de hjemlige egne, og med sig bragte de naturligvis noder. Det var imidlertid ikke kun gennem sådanne rejser, at musik blev spredt. Noder var også en handelsvare, som indgik i sortimentet hos tidens handelsmænd, og som effektivt blev mangfoldiggjort gennem trykkemediet. Boghandlere og andre købmænd kunne gennem deres organiserede handelsruter og personlige netværk på tværs af kontinentet fremskaffe noder med musik fra snart sagt alle egne af Europa. Den tyske komponist og musikteoretiker Michael Praetorius (1571-1621) står som en af tidens bedste nordeuropæiske kendere af italiensk musik, og selvom han så vidt vides aldrig selv besøgte Italien, må han have haft adgang til store mængder musik af italienske komponister. Fra sin centrale position i Tyskland ved hoffet i Wolfenbüttel havde han kontakter, som kunne tilvejebringe den eftertragtede musik. Boghandleren Kaspar Flurschütz fra Augsburg havde specialiseret sig i at importere noder fra Italien, og man ved, at Praetorius havde kontakt til ham for at orientere sig om nye udgivelser. ${ }^{1}$ Også i mere perifere egne kunne man anskaffe udenlandsk musik, såsom på Katedralskolen i Ribe, som i slutningen af 1500-tallet

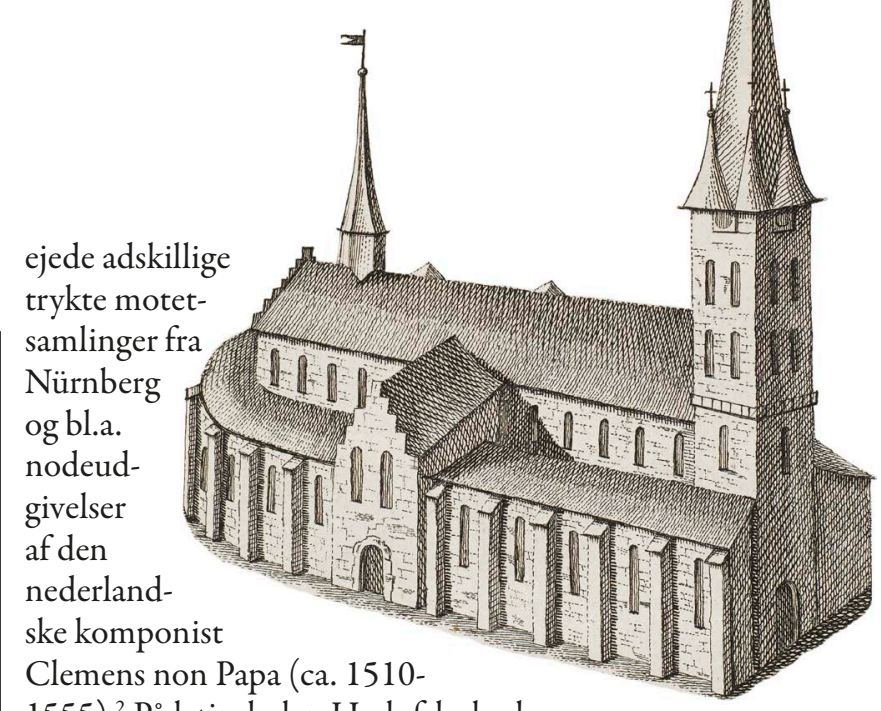

1555). . På latinskolen Herlufsholm hav-

de man omkring år 1600 musik af tidens

fremtrædende italienske komponister,

Orazio Vecchi (1550-1605) og Giovanni

Gabrieli (ca. 1554-1612). ${ }^{3}$ Værkerne stam-

mede overvejende fra trykte nodesamlin-

ger, som det ikke var nødvendigt for de

musikkyndige selv at rejse udenlands for

at komme i besiddelse af.

Denne artikel kaster lys over nodehandlen i København i 1600-tallet og tegner et billede af tilgængeligheden af noder. På denne tid var byen et centrum for boghandel i Skandinavien, og med talrige udenlandske boghandlere i byen foregik der en betydelig import af bøger fra kontinentet. Boghandlerne havde udsalgspladser på byens livlige steder, blandt andet på Børsen og i og omkring Vor Frue Kirke, hvor handlende kunne komme i berøring med tidens nyeste udgivelser. ${ }^{4}$ Byens boghandlere stod også bag importen af nodeudgivelser til hovedstaden, og som det skal vise sig i denne artikel 
dannede deres aktiviteter grundlag for en langt større tilgængelighed af udenlandsk musik i 1600-tallets København, end det hidtil har været kendt.

Ligesom andre bogudgivelser blev også noder præsenteret på bogmesserne i Frankfurt og Leipzig siden 1500-tallet. Tidens nyeste bogudgivelser var at finde her, og følgelig blev de to byer samlingspunkter for forlæggere og boghandlere. I begyndelsen af 1900-tallet satte musikforskeren Albert Göhler fokus på de bogkataloger, som siden 1564 var blevet distribueret fra messerne med information om udbuddet af bøger. Med sine studier tegnede Göhler et billede af det enorme udvalg af musiktryk, som var tilgængeligt for besøgende på messerne. ${ }^{5}$ Katalogerne viste sig således at være en vigtig type kilde til at forstå forskellige musikhistoriske tematikker, for eksempel som et billede på bestemte komponisters popularitet. Det er imidlertid først indenfor de seneste årtier, at musikforskere atter har rettet blikket mod bogmesserne for at vise, at de var et afgørende centrum for nodehandel, og at handelsaktiviteterne til og fra messerne var afgørende for spredningen af musik i den tidlige moderne tid. ${ }^{6}$ Ofte foregik det sådan, at boghandlere foretog rejser til messerne for at indkøbe bøger på vegne af deres kunder eller for at forny deres sortiment af nyudgivelser. Også musikere og komponister besøgte messerne, bl.a. Heinrich Schütz, hvorved de ved selvsyn kunne inspicere det store udvalg af noder. Selvom enkeltpersoner besøgte messerne, fremstod særligt tyske boghandlere med deres organiserede handel som centrale aktører i distributionen af noder til deres lokalegne. Også københavnske boghandlere foretog rejser til bogmesserne i Frankfurt og Leipzig for at indkøbe bøger og noder til deres boglader i København. For at få bevilget en salgsplads i Vor Frue Kirke, forpligtede boghandlerne sig til at holde deres sortimenter opdateret ved at besøge de tyske messer. ${ }^{7}$ På denne måde sikrede universitetets rektor, som havde patronatsret over byens hovedkirke, at den nyeste viden tilstrømmede de intellektuelle miljøer. Denne tilstrømning nød også byens musikere godt af.

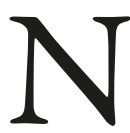
odehandel i 1600-tallet er et emne, som kun har tiltrukket ganske lidt opmærksomhed gennem tiderne, når det drejer sig om danske forhold. Dette skyldes, at nodehandel i København først blev etableret som en selvstændig branche i løbet af 1700-tallet, ${ }^{8}$ men import og salg af noder i hovedstaden foregik imidlertid allerede i 15 - og 1600-tallet. Denne 'forhistorie' giver os mulighed for at danne os et billede af, hvordan musikudøvere i hovedstaden kom i besiddelse af nye noder. For hvad gjorde en musiker, når vedkommende ville forny sit repertoire og anskaffe nye noder? En interessant dansk kilde, som giver os et indblik i dette, er manuskriptet Musicus Danicus (1687) af Matthias Henriksen Schacht (1660-1700). .' Schacht var efter studier ved Københavns Universitet blevet rektor på latinskolen i Kerteminde, hvor han forfattede det nævnte skrift. Teksten består af en række forskellige musikteoretiske afhandlinger, bl.a. om kunsten at synge, om komposition og om, hvordan man spiller generalbas. De første sider af manuskriptet er en personfortegnelse, hvor Schacht først og fremmest opregner navne på komponister, hvis musik han på den ene eller anden måde havde stiftet bekendtskab med. Listen indeholder kun sparsomme biografiske 


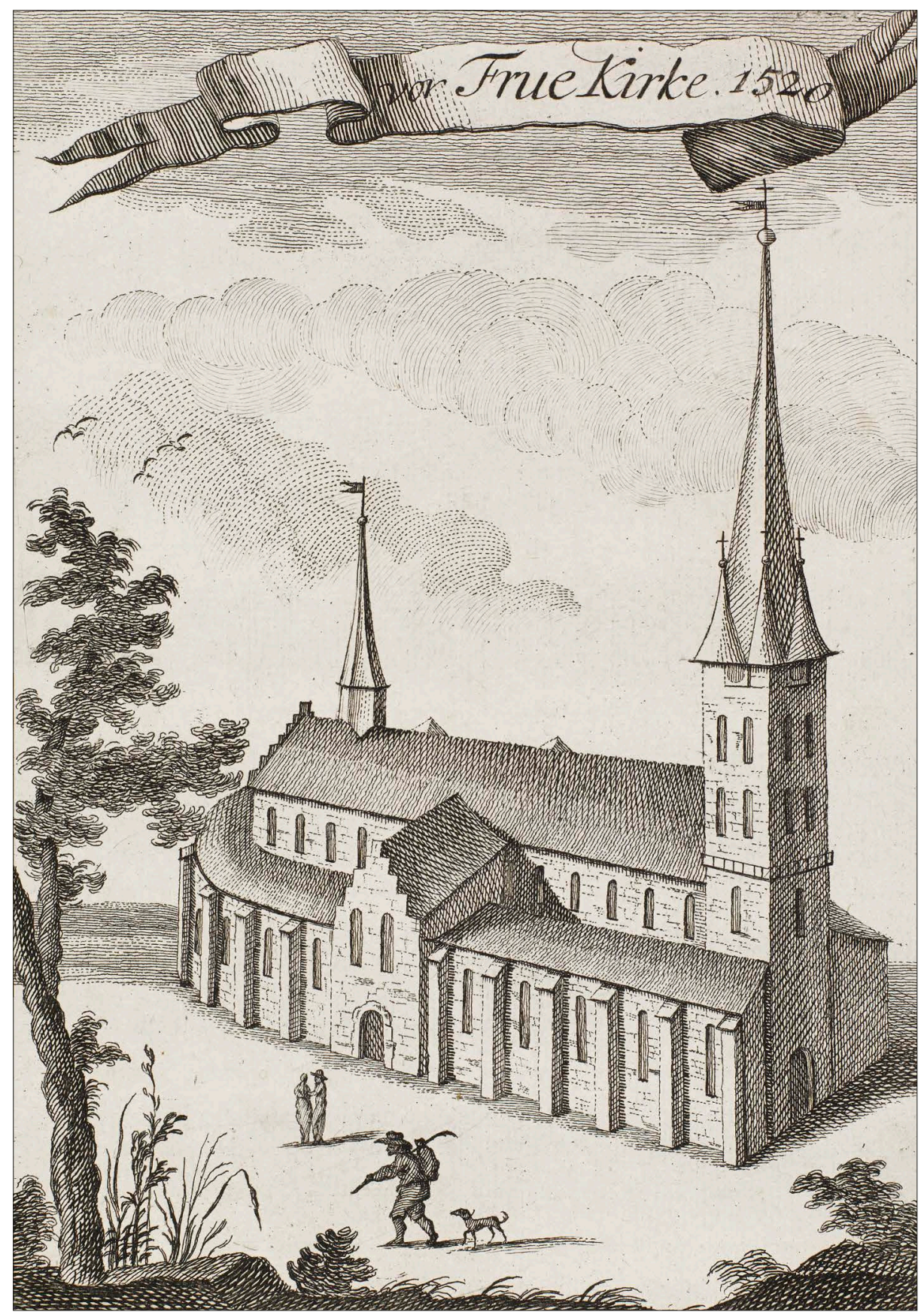

Sidekapellerne i Vor Frue Kirke blev anvendt som boglagre for byens boghandlere. 
oplysninger, hvilket vidner om, at Schacht overvejende var interesseret $\mathrm{i}$ komponisternes produktion og oplysninger om, hvor hans kendskab til konkrete værker stammede fra. Listen er interessant, fordi den løfter sløret for omfanget af tidens nodeudbud i Danmark, og fordi den bekræfter, at musik af udenlandske komponister fortrinsvis var kendt gennem trykte noder. Særligt udbredte var tidens populære motetantologier Floreligium Portense (Leipzig 1618 og 1621), Promptuarii musici (Strasbourg 1611, 1612, 1613 og 1617) og Geistliche Concerten (Leipzig 1641, 1642 og 1646). ${ }^{10}$ Komponister såsom Andrea Gabrieli (1532/3-1585) og Giovanni Rovetta (ca. 1595-1668), der i dag gælder som nogle af tidens fremtrædende komponister, kendte Schacht kun gennem disse trykte samleværker. ${ }^{11}$

Listen giver også indtryk af, hvordan Schacht kom i besiddelse af nodeudgivelser. Flere steder i sin fortegnelse meddeler han, at musik af den pågældende komponist var til salg i København. Det var tilfældet med adskillige arier af den italienske komponist Alessandro Grandi (1586-1630). ${ }^{12}$ Schacht nævner tilmed specifikke udgivelser, som kunne erhverves i byen, eksempelvis Ambrosius Profius' Cunis solennibus Jesuli (1646), en samling italienske julemotetter, og Musicalischen Moralien (1639). ${ }^{13}$ Der er næppe nogen tvivl om, at Schacht med sådanne anmærkninger refererede til det udsalg, som byens boghandlere forestod. Et par enkelte steder i fortegnelsen nævnes boghandlerne da også ved navn, og vi erfarer således, at man hos boghandlere som Peter Haubold og Johann Melchior Liebe kunne købe Fidel Molitors udgivelse Cantiones Sacra (Innsbruck 1664) og musik af en vis Kittelius. ${ }^{14}$ Også Tobias Eniccelius'
Melismata Epistolica (Kiel 1667), en samling festepistler for én vokalstemme, to instrumenter og generalbas, var til salg hos Liebe. ${ }^{15}$

$\mathrm{P}$ å trods af, at Schacht generelt er sparsom med sine oplysninger, afslører hans fortegnelse detaljer om, hvordan han skaffede information om udgivelser, der var til salg. Det mest nærliggende er, at han selv besøgte boghandlerne. Men af hans noter fremgår det, at han ikke nødvendigvis opsøgte dem i egen person for at holde sig orienteret om nodeudbuddet i byen. Om musikudgivelser af den sydtyske komponist Felician Schwab skriver han nemlig, at de blev annonceret i et udsalgskatalog af Peter Haubold i $1672 .{ }^{16}$ Når Schacht andre steder i sin liste angiver, at musik af navngivne komponister kunne købes i København, kunne hans oplysninger muligvis stamme fra boghandlernes kataloger. Schacht orienterede sig også internationalt gennem tyske kataloger, og således angiver han, at en ukendt missa af Spiridion (1615-1685) kunne købes i både København og Leipzig. ${ }^{17}$ At boghandlerne forhandlede musik, som vi i dag ikke har kendskab til, kan skyldes (udover at de naturligvis er gået tabt), at de ikke kun forhandlede trykte bøger, men også håndskrevne noder fremstillet af professionelle nodeskrivere. ${ }^{18}$

Schachts henvisninger til, at københavnske boghandlere annoncerede med nodeudgivelser i deres bogkataloger, leder os på sporet af flere oplysninger om byens nodehandel. At dømme ud fra bevarede bogkataloger fra 1600-tallet var det ikke almindeligt for byens boghandlere at reklamere for noder. Dette kan være en af årsagerne til, at handel med noder $\mathrm{i}$ 
København i 1600-tallet har været et overset emne i den eksisterende forskning. Af de mange bevarede kataloger, som bl.a. boghistorikeren Harald Ilsøe har undersøgt, indeholder kun ganske få kataloger oplysninger om nodesalg i byen. ${ }^{19}$ Det ringe antal betyder dog næppe, at det ikke var almindeligt for byens boghandlere at forhandle noder, også selvom det ikke fremgik eksplicit af salgskatalogerne. Nogle kataloger er temmelig ukonkrete i beskrivelserne af, hvilket sortiment der forhandledes. Et katalog af Georg Holst (Jørgen Holst) fra 1664 angiver på sidste side, at han havde "10 Musikalske Bøger" på sit lager. ${ }^{20}$ Det virker ikke som en overvældende mængde noder, hvis man overhovedet kan være sikker på, at der hentydes til noder og ikke bøger om musik. Det over 100 sider lange katalog var en opgørelse over det boglager, som Holst efterlod sig efter sin død. Det vidner således kun om, at han forhandlede musikudgivelser og ikke om størrelsen af hans sortiment.

Når konkrete udgivelser opremses i katalogerne, forekommer de som regel i stikordsform med angivelse af komponistens efternavn og med en kort titel på værket eller blot med et enkelt karakteristisk ord. For læseren af katalogerne krævede det derfor et forhåndskendskab for at kunne vide, hvilke værker den sparsomme information dækkede over. Alternativt måtte musikeren gætte sig til, om den pågældende udgivelse var værd at anskaffe. Vi skal derfor forestille os, at selvom udenlandske noder var tilgængelige for kunderne, var det nok vanskeligt at danne sig et indtryk af, hvilken musik det drejede sig om. Ydermere skal man tænke på, at boghandlerne nok ikke stod inde for musikkens kvalitet. En komponist som
Heinrich Schütz nævner i et af sine breve, at han kun med stort besvær anskaffede musik af de allerfornemste komponister i Europa. ${ }^{21}$ En sådan kræsen udvælgelse var stadig vanskelig, også selvom den lokale boghandler kunne hjælpe med at tilvejebringe noderne. Selvom Schütz som nævnt drog fordel af tidens boghandlervæsen, ved vi samtidigt, at han sørgede for at få personlig kontakt til de komponister (eller personer i deres omgangskreds), hvis musik han var på udkig efter. ${ }^{22}$

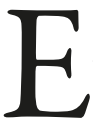
$n$ boghandler, der som en del af sin virksomhed i København solgte noder, var Joachim Moltke. Han var oprindelig fra Rostock, men havde i 1626 slået sig ned i Danmark som bestyrer af en boglade. Kort tid efter startede han sin egen forretning, som han drev indtil sin død i 1664. To kataloger fra hans virksomhed kaster interessant lys over vores historie. Da Moltke døde, blev der udfærdiget et katalog over hans efterladte boglager, og det vidner om, at han gennem en længere årrække forhandlede noder. ${ }^{23}$ På den lange liste forekommer en mængde musikudgivelser, såsom gamle motetsamlinger fra München og Nürnberg og udgivelser med musik af bl.a. Orlando di Lasso (1532-1594) og Michael Praetorius. Ud over danske udgivelser fokuserede Moltke desuden på musik fra sin hjemby. Vi finder bl.a. musik af Daniel Friderici (1584-1638) og Nicolaus Hasse (1617-ca.1670). Dette vidner om, at hans handelsmæssige forbindelser til Tyskland fortsatte gennem tiden i Danmark. Det tyske marked var desuden en vigtig aftager af de bøger, som han selv var forlægger på, og således annoncerede han flittigt i katalogerne fra Frankfurt og Leipzig. ${ }^{24}$ I 1667 blev Moltkes private bibliotek 


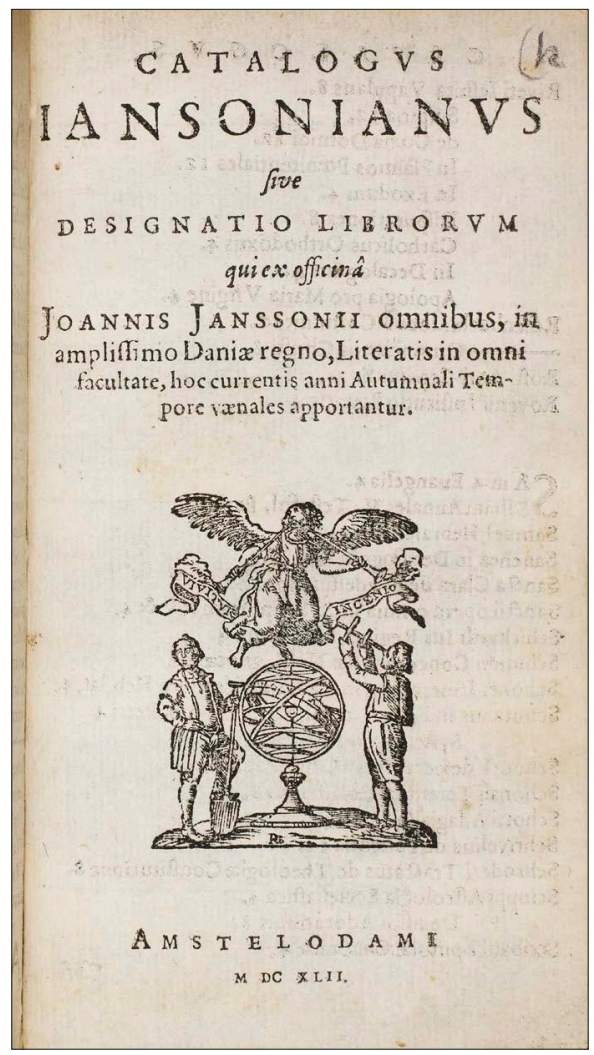

I I R O R V M. IIJ

\section{Mufici.}

A Bozzi overo Capprici diAnion. Guelfi à Vake
Sola, fol. Affetti Amorofi di Marco Antonio Negri à Voce So$\mathrm{la}, \mathrm{fol}$.

Airs de Claude le leune à 3.4.5. \& 6.parties, 8. Apollinis Gúffe Lener Valetti à 2. Voc. 4. Arie Muliche di Felice Sanci à $1 . \& 2$. Voci, fol. Arie Mufiche di Francif́o Negri à 1. \& z. Voci, fol. Arie Mufiche di Lauro Fumo à I. \& 2. Voci, 4. Asmonie Spirituali di Alberto Lazari à 1.2 .3 .4 .5. \& 6. Voci, 4.

Ariofi Concerti di Gregorio Sanefe à x. \& 2. Voci, , 4a

R Arca di Venetia Madrigali à s. Voci di Adr: BanBizzarris Poëtiche di Nicolo Fontei Orcianefe libro Secondo à 1. 2. 8. 3. Voc: fol.

Anzonette di Gregorio Zuchini à 3. Voci, 4.

Anzonette di Gregorio 10.12.14.15.822. Voci, 4.

Canzoni da Sonare à 4. Voci di Antonio Mortaro, 4. Canzoni overo sonate Concertate di Tarq. Merula à 2. \& 3. Voci, fol.

Caprici Canzon Francefe di Girol: Frefcobaldi, fol.

Concentus Armoniaci Peregrini Pofcentii, 2.3. \& 4. Inftr: fol.

Concerti di Camera di Giac: Arrigoni à 2.3.4.5.6.7. 8. \& 9. Voci,8.

Cancerti

Jan Janssons katalog fra 1642 indeholdt 57 titler på musiktryk, der kunne købes fra hans udsalgspladspå Børsen.

bortauktioneret, og kataloget herfra viser, at han også personligt interesserede sig for musik. ${ }^{25}$ Blandt hans bøger forekom bl.a. instrumentalmusik af førnævnte Hasse og det musikteoretiske skrift Heptachordum Danicum (København 1646). Netop denne udgivelse forhandlede Moltke selv, og ved sin død efterlod han sig også flere eksemplarer af det på sit lager. Ud fra profilen af Moltkes virksomhed er det ikke vanskeligt at forestille sig, at han importerede noder på vegne af københavnske musikere. Hvordan dette nærmere foregik, ved vi på nuværende tidspunkt imidlertid intet om.
Moltke og Holst var begge bosatte i København og førte her deres privatliv ved siden af deres professionelle virke som boghandlere. I modsætning til dem står den hollandske Jan Jansson som et eksempel på en udenlandsk forhandler, der havde sit hovedsæde i Amsterdam og samtidigt drev en satellitbutik fra en udsalgsplads på Børsen i København. I to kataloger fremgår det, hvilke bøger han solgte her, og de vidner også om importen af noder til København. Jansson udgav katalogerne i Amsterdam med bemærkningen om, at bøgerne var til salg for enhver i det danske rige, og derfor kan 
man betragte Janssons sortiment som særligt tilpasset danske købere. ${ }^{26}$ På den baggrund er det interessant at konstatere, at udvalget af noder adskilte sig markant fra det, som hans tyske kolleger havde.

Størstedelen af de nodetryk, som Jansson forhandlede i 1642, stammede fra Italien.

Janssons sortiment var på den ene side alsidigt. Her var både vokalmusik og instrumentalmusik, verdslig musik og gejstlig musik, musik for ensembler og musik for soloinstrumenter (eksempelvis tasteinstrumenter). På den anden side havde Jansson fortrinsvist udvalgt musik af italienske eller nederlandske komponister, af de sidstnævnte bl.a. Nicolas Vallet (1583-1642), hvis udgivelser Jansson selv havde været forlægger på. Angående den italienske musik var der en overvægt af udgivelser fra Venedig. Det er sandsynligt, at Jansson havde kontakter i denne by, og det forekommer helt naturligt, at byen er så markant repræsenteret set i forhold til den enorme produktion af musiktryk herfra på denne tid. Komponister som Giovanni Gabrieli, Claudio Monteverdi (1567-1643) og Giovanni Felice Sances (ca. 1600-1679) er blandt de fremtrædende komponister fra denne by, hvis værker blev forhandlet af Jansson i København.

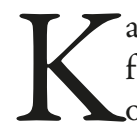
ataloget viser, at Jansson havde fundet sine egne nicheområder og tilpasset sit sortiment herefter. Dette betød bl.a., at de kirkelige værker, han solgte fra sin boglade, overvejende var af katolske komponister. Dette gjorde ikke værkerne usælgelige i protestantiske Danmark - tværtimod. Jansson adskilte sig hermed fra det protestantiske sortiment, som de tyske boghandlere i byen forhandlede, og han kunne på den måde tilbyde et repertoire, som var eftertragtet og ofte uden videre kunne anvendes i en protestantisk-liturgisk sammenhæng.

I sit manuskript giver Schacht udtryk for, at han kom i besiddelse af musik gennem københavnske boghandlere. Men var det en almindelig fremgangsmåde, når man skulle anskaffe sig nye noder? Tilsyneladende, ja, for byens professionelle musikere, hofmusikerne på slottet og kirkemusikerne, handlede her også. Vi ved, at hofmusikere i begyndelsen af 1620 'erne foretog nodeindkøb hos byens boghandlere, bl.a. hos universitetstrykkeren Salomon Sartor og Jørgen Holst. ${ }^{27}$ Selvom kapellet havde en stærk international profil, var det kun danske musikere, som indkøbte noder på vegne af hoffet. En helt praktisk årsag til dette kunne være, at de bedre kunne kommunikere med de københavnske boghandlere, når de foretog indkøbene. Imidlertid fik de rådgivning af deres udenlandske kolleger. En fortegnelse med italienske nodeudgivelser er bevaret i hoffets arkiver. Det var den italienske sanger Gregorio Chelli da Verona, som på denne tid rådgav hoffet om, hvilken musik der kunne være nyttige for kapellet at stifte bekendtskab med. På listen har Christian IV tilføjet en befaling om, at rentemestrene skulle anskaffe noderne. ${ }^{28}$ Det har formentlig været en overkommelig opgave, som kunne overdrages til en af byens boghandlere.

Også på byens latinskole, som $\mathrm{i}$ århundrederne efter reformationen indtog en central position som musikalsk vækststed i byen, vendte man sig mod boghandlerne, når det musikalske repertoire skulle fornyes. Boghandlerne var vigtige leverandører af skolematerialer såsom papir, tavler, læsebøger og noder. Vi kan forestille os, at der har været 
daglig kontakt mellem skolens personale og boghandlerne, for i forbindelse med de kirkelige handlinger i Vor Frue Kirke kunne skolens sangerdrenge og lærerne komme lige forbi boghandlernes lagre i sidekapellerne. Tilmed havde førnævnte Joachim Moltke en aftale om at benytte skolens loft til at opbevare sine bøger. ${ }^{29}$ Således havde skolens lærere ingen problemer med at skaffe noder, og gennem store dele af århundredet indkøbtes drypvis motetsamlinger og lignende værker til det daglige musikalske arbejde i byens kirker. Et omfangsrigt regnskab i skolens arkiver giver et indtryk af, at skolen i tiårene efter 1650 ejede skønsmæssigt op mod 100 forskellige nodeudgivelser..$^{30} \mathrm{I}$ en periode på mindre end 10 år blev der brugt store pengebeløb til anskaffelse af nye noder, svarende til to årslønninger for kantoren. Den daværende biskop, Jesper Brochmand, havde bevilget pengene ekstraordinært for at forbedre musikken i byens sognekirker. Det ligger udenfor rammerne af denne artikel at belyse, hvilke konkrete værker, det drejede sig om, men det kan kort sammenfattes, at repertoiret var alsidigt og spændte fra små koncerterende satser til stort anlagte værker med instrumental ledsagelse.

De professionelle musikere i byen var afhængige af velorganiserede nodeforhandlere, som kunne tilvejebringe udgivelser med den ønskede musik. Selvom nodehandel som nævnt først blev en selvstændig branche i 1700-tallet, tyder det på, at de københavnske boghandler formåede at løfte opgaven allerede i 1600 -tallet. Vi ved nemlig, at der indkom bestillinger fra latinskolen i Kristiania (nu Oslo) på velegnede liturgiske værker til opførelse ved byens kirker. ${ }^{31}$
I et større perspektiv viser byens boghandlere sig at have været vigtige aktører i den kulturudveksling, der foregik i Europa på denne tid. Noder var i sig selv ikke en vare, der kunne opretholde sin egen organiserede handel, men gennem det etablerede boghandlervæsen kunne en lokalitet som København forsynes med musik fra ellers fjerne egne som Italien. Importen af noder til byen blev udnyttet af lokale musikere, og byens forskelligartede boglader viser sig således at have været en vigtig medspiller for byens musikalske aktører, når de skulle i besiddelse af nye noder. Hvis musikerne ikke selv havde mulighed for at tage på udenlandsrejser og eksempelvis besøge bogmesserne i Frankfurt og Leipzig, var byens boghandlere vigtige samarbejdspartnere. Denne historie giver et enestående indblik i tidens musikliv i København, og selvom vi mangler en mængde information for fuldt ud at forstå, hvordan musikere kom i besiddelse af ny musik, får vi et indblik $i$, hvilke muligheder tidens professionelle musiker stod overfor. Med den udprægede nodehandel, der foregik i København i 1600-tallet, er det værd at tage vores forstålse af dansk musikhistorie op til genovervejelse. Det var ikke kun på rejser til udlandet, at man kunne komme i besiddelse af tidens nyeste nodeudgivelser. Der er således ikke noget mærkværdigt $i$, at udenlandsk musik havnede $i$ hænderne på danske musikere og lå til grund for deres daglige musikudøvelse. En rejse til Nürnberg eller Norditalien var ikke påkrævet. Danmark var ikke et land i Europas periferi, men gennem det institutionaliserede boghandlervæsen forbundet med centraleuropæiske kulturcentre. 
Artiklen er en lettere revideret udgave af artiklen "Nodehandel i Kobenhavn i 1600-tallet" bragt $i$ Custos. Tidsskrift for tidlig musik, 11:3, september 2013, s. 14-17.

\section{Noter}

1 Richard Schaal: Die Kataloge des Augsburger Musikalien-Händlers Kaspar Flurschütz, 1613-1628 (Quellenkataloge zur Musikgeschichte 7), Wilhelmshaven 1974. Ang. Praetorius' forhold til Flurschütz se: Stephen Rose: The Mechanisms of the Music Trade in Central Germany, 1600-40. Journal of the Royal Musical Association, 130/1, 2005, s. 1-37, især s. 12-13.

2 Bengt Johnsson: Den danske skolemusiks historie indtil 1739 (Studier fra Sprog- og Oldtidsforskning 284), 1973, s. 54-58.

3 John D. Bergsagel: Foreign Music and Musicians in Denmark During the Reign of Christian IV. Anne Ørbæk Jensen og Ole Kongsted (red.), Heinrich Schütz und die Musik in Dänemark zur Zeit Christians IV., 1989, s. 19-24; Ole Kongsted: Herlufsholm-samlingen: R 121-125 og danskerne i Italien omkring 1600. John T. Lauridsen og Olaf Olsen (red.): Umisteligt. Festskrift til Erland Kolding Nielsen, 2007, s. 101-118.

4 Om boghandel i København se bl.a.: Aleksander Frøland: Dansk boghandels historie 1482-1945. Med et kapitel om bogen i oldtid og middelalder, 1974; Harald Ilsøe: Bogtrykkerne i Kobenhavn og deres virksombed ca. 1600-1810: en biobibliografisk haindbog med bidrag til bogproduktionens historie (Danish Humanist Texts and Studies 5), 1992, s. 39-82; Charlotte Appel: Lasning og bogmarked i 1600-tallets Danmark (Danish Humanist Texts and Studies 23), 2001, særligt s. 470-479.

5 Albert Göhler: Die Messkataloge im Dienste der musikalischen Geschichtsforschung. Eine Anregung zur zeitgenössischen Bücherbeschreibung, Leipzig 1901; Albert
Göhler: Verzeichnis der in den Frankfurter und Leipziger Messkatalogen der Jahre 1564 bis 1759 angezeigten Musikalien, Leipzig 1902.

6 Et par udvalgte eksempler er: Rose 2005; Rudolf Rasch (red.): Music Publishing in Europe 1600-1900. Concepts and Issues, Bibliography (Musical Life in Europe 1600-1900. Circulation, Institutions, Representation. The Circulation of Music vol. I), Berlin 2005; Birgit Lodes (red.): Niveaunischenimbus. Die Anfänge des Musikdrucks nördlich der Alpen

(Wiener Forum für ältere Musikgeschichte 3), Tutzing 2010; Jane A. Bernstein: Print Culture and Music in Sixteenth-Century Venice, Oxford, 2001; Hans Lenneberg, On the Publishing and Dissemination of Music, 1500-1850, Hillsdale 2003.

7 Frøland 1974, s. 51-52, 68-69; Ilsøe 1992, s. $39-42,44$.

8 Nils Schiørring: Musikkens Historie i Danmark, 1, 1977, s. 139-142.

9 Musicus Danicus eller Danske Sangmester, ms. dateret 1687. Det Kongelige Bibliotek, NKS $109 \mathrm{k}$ folio.

10 Om udbredelsen af musik gennem antologier se bl.a.: Jerome Roche: Anthologies and the Dissemination of Early Baroque Italian Sacred Music, Soundings, 4, 1974, s. 6-12.

11 Bjarke Moe: Musikkulturel trafik i København og Rostock. Musikerrekruttering og repertoirefornyelse i forste halvdel af 1600-tallet, ph.d.-afhandling, Københavns Universitet 2010, bd.1, s. 123-124.

12 I det følgende refereres til Godtfred Skjernes transskription af manuskriptet: Matthias Henriksen Schacht. Musicus Danicus eller Danske Sangmester, 1928, s. 38.

13 Skjerne 1928, s. 19.

14 Ibid., s. 56, 62.

15 Ibid., s. 33.

16 Ibid., s. 70.

17 Ibid., s. 40, 71.

18 Rasch (red.) 2005, s. 64-66. 
19 Se bl.a. Harald Ilsøe: Biblioteker til salg. Om danske bogauktioner og kataloger 1661-1811 (Danish Humanist Texts and Studies 31), 2007.

20 Catalogus librorum Miscellaneorum Bibliopole Georgii Holst, 1664 (mikrofilm, Det Kongelige Bibliotek), s. 124. Omtales i Ilsøe 2007, s. 54.

21 Michael Heinemann (red.): Schriftstücke von Heinrich Schütz (Schütz-Dokumente 1), Köln 2010, s. 179.

22 Bjarke Moe: Heinrich Schütz as European cultural agent at the Danish courts. Schütz-Jahrbuch, 33, 2011, s. 129-142, særligt s. 138 og 142.

23 Catalogus librorum miscellaneorum compactorum qvorum auction (deo volento) die xxix. octobris habebitur inedibus vidue Joachimi Moltkenii, 1666 (mikrofilm, Det Kongelige Bibliotek).

24 Ingrid Ilsøe: Boghandleren Joachim Moltke og hans virksomhed 1626-1664. Fund og Forskning, 24, 1980, s. 63-92, særligt s. 72-77.

25 Libri bibliothece Moltkeniane miscellanei tàm compacti, quam incompacti qvorum auctio habebitur (deo volente) in edibus regentianis die 19. februarii 1667, 1667 (Hielmst. $13274^{\circ}$, Det Kongelige Bibliotek).
26 Catalogvs Librorvm, qui ex officina Joannis Ianssonii omnibus, in amplissimo Danice regno, Literatis in imno facultate, hoc currentis anni autumno, venales exhibentur, Amsterdam 1641, (Udtaget småtryk 50,-18 8 $8^{\circ}$, Det Kongelige Bibliotek), s. 72; Catalogvs Iansonianvs sive designatio librorvm qui ex officinâ Joannis Janssonii omnibus, in amplissimo Danie regno, Literatis in omni facultate, hoc currentis anni Autumnali Tempore venales apportantur, Amsterdam 1642 (Udtaget småtryk 50,-18 8º , Det Kongelige Bibliotek), s. 113-115.

27 Moe 2010, bd.1, s. 131-134.

28 Bjarke Moe: Italian Music at the Danish Court during the Reign of Christian IV. Presenting a Picture of Cultural Transformation. Danish Yearbook of Musicology, 38, 2010-2011, s. 15-32, særligt s. 20-21.

29 Ilsøe 1980, særligt s. 64-65; Moe 2010, bd.1, s. 153-154.

30 Moe 2010, bd.1, s. 155-160. Se en transskription af regnskabet i bd.2, s. 34-37.

31 Hampus Huldt-Nystrøm: Hva sang disciplene ved Christiania Kathedralskole i 1600-årene?. Studia Musicologica Norvegica, 5, 1979, s. 27-48. 